\title{
The Role of Public Policies in Enhancing Cultural and Creative Industries: An Analysis of Public Policies Related to Music in Colombia
}

\author{
Flor Marleny Gómez-Reyes (D), Daniel Catalá-Pérez $(\mathbb{D}$, \\ and María de-Miguel-Molina $(\mathbb{D}$
}

\section{Introduction}

The creative industries concept was first used in 1994, in Australia, when the Creative Nation report was published (UNESCO, 2013). However, its major impact came in 1997 when the Department of Culture, Media and Sports created the Working Group of Creative Industries in the United Kingdom (UNCTAD, 2010). Since then, the United Kingdom has been very active in spreading the idea of cultural and creative industries (CCIs) in the European Union. According to the United Nations, CCIs are those that "create, produce and deliver products and services using intellectual capital as their main income" (UNCTAD, 2008, p. 20) and they are of great importance for regional economic development, especially in developing countries (UNESCO Forum of Ministers of Culture, 2019).

The cluster concept has a long-standing tradition in literature (Cooke et al., 2006). Its central argument is that when similar competing businesses are located in the same district and share skills and ideas, enabling mutual inspiration (Islam, 2000), they are more effective. Clusters have been especially attractive in the creative and cultural industries (UNESCO, 2019). Concentrating CCIs in clusters can enhance their intellectual capital (Baculáková, 2018) because the core of knowledge is based on collective learning (Bialic-Davendra et al., 2016; UNCTAD, 2008). Moreover, CCI clusters can support SMEs (Zheng \& Chan, 2014), which are the typical size of companies in this sector.

\footnotetext{
F. M. Gómez-Reyes ( $\square)$

Universidad Tecnológica de Bolivar, Cartagena, Colombia

e-mail: fgomezr1@ucentral.edu.co

D. Catalá-Pérez · M. de-Miguel-Molina

Universitat Politècnica de València, Valencia, Spain

e-mail: mademi@omp.upv.es
} 
CCIs tend to be concentrated in geographical areas which have the characteristics of a metropolitan area, such as large cities (Boix et al., 2011). In these areas, the local productive system is more concentrated and CCIs have a greater impact on economic activity. Bogota, Colombia's capital city, is an example of these geographical areas.

However, due to the different types of agglomerations associated with cities, three approaches can be applied to an analysis of CCIs in Bogota: pure agglomeration (geographical proximity), complex industry (minimising transaction costs) and/or social network (high levels of social integration). In this study, however, we focus only on a pure agglomeration analysis to assess the concentration of "hot spots" in a city, in line with Boix et al.'s (2011) study of 16 European cities.

In this analysis, the authors established four categories of clusters: (i) economies with low urbanisation, which are formed in isolation and are usually made up of specialised companies; (ii) high levels of polycentrism, with the formation of groups with similar specialisations that facilitate synergies; (iii) low levels of polycentricity and high urbanisation, centred on a single point in the city due to an urban structure whose orography does not allow expansion and benefits from complementarities; (iv) and polycentrism, which occurs in large cities when there is income speculation that causes a rise in revenue, making it difficult to concentrate clusters in one point. This environment encourages creative environments (Boix et al., 2011, p. 757).

The process of creating public policies goes through different stages: identifying and defining the problem, obtaining information, developing different alternatives, selecting the criteria to implement them and evaluating their results (Bardach, 1998). In the case of CCI policies, different international organisations and institutions agree that public intervention focuses on eight main areas: institutions and regulatory frameworks (to promote favourable conditions), information and knowledge (for continuous communication), human resources and learning (development tools), infrastructure (spaces for CCIs), financing (direct, indirect and self-sustainable), markets and population (satisfying demand through goods supply), cooperation (networks) and creativity and innovation (depending on the social and political context) (Organización de Estados Iberoamericanos, 2016).

In the area of cooperation and integration, the advocacy and strengthening of joint initiatives in the creative sector involve promoting creative districts (Organización de Estados Iberoamericanos, 2016, p. 159). Nevertheless, cooperation must go hand in hand with government measures to find sustainable financing and communication strategies to develop and encourage innovation, training and constant reskilling for CCI actors (Organización de Estados Iberoamericanos, 2016, p. 167).

Any policy on culture and creativity must include economic objectives such as equity, efficiency, a positive trade balance, economic development and full employment, to ensure positive impact on the well-being of consumers and CCI services. Furthermore, to obtain a good balance between supply and demand, sufficient quality production is necessary, enhancing creative processes and guaranteeing a culture of consumption of CCIs at national and international levels, as well as scenarios to reinforce diversity, design, own brand and connectivity (Organización de Estados Iberoamericanos, 2016). 
Moreover, for clusters to be able to revitalise a sector, such as the music industry, there must be a governance model that generates success and sustainable competitiveness (Cooke \& Lazzeretti, 2008). For example, during the recession of the 1970s, the governments of the United States and Western Europe developed strategies to regenerate their city centres through public policies to increase cultural and creative consumption (Binns, 2005).

\section{Background}

\subsection{Policies in Colombia and Bogota}

In Colombia, cultural policies were introduced in the 1970s. In 1976, the Colombian Institute of Culture launched its first cultural development plan, "Cultural policy in Colombia", which included the cultural history of Colombia from its aboriginal cultures, the founding of cities, political independence through to the development of education and literature, and took in the country's cultural and natural heritage (Ruiz $\&$ Marulanda, 1976). From the 1980s onwards, different policies and regulations for CCIs and cultural support were developed: six from 1982 to 1989, nine from 1991 to 1997 and eight from 2000 to 2017.

CCI policies are currently included in the 2018-2022 National Development Plan (NPD) and, in 2019, a Vice Ministry of Orange Economy was created, under the Ministry of Culture. This NPD is also aligned with the United Nations' Sustainable Development Goals (SDGs) (UNESCO, 2019). Today, Colombia has divided CCIs into three areas and there are around 25 public policies for their improvement. As we can see (Fig. 1), there are three main areas for CCIs: arts and heritage (17 public policies), cultural industry (4 public policies) and functional creations or creative services ( 2 public policies). In addition, two crosscutting public policies are applied to the three areas.

Figure 2 shows that the main efforts have focused on the arts and heritage. However, this area only provides $28.3 \%$ of CCIs' added value ${ }^{1}$ in Colombia, while the creative services area contributes $44.4 \%$ and cultural industries $27.3 \%$. CCIs contributed 3.2\% to Colombia's global economy in 2018 (DANE, 2019).

On the other hand, cluster policies have gained importance in Colombia since its Competitiveness Private Council (CPC) together with the International Trade Bank (Bancoldex), through its Development and Innovation Unit (Inpulsa), signed a cooperative agreement in 2013 to create a cluster network in Colombia. In the field of CCIs, this trend to promote clusters has been reinforced through the District

\footnotetext{
${ }^{1}$ Added value: "Additional value created by an economic agent through the production process. It is obtained from the difference between the value of production at basic prices and the value of intermediate consumption at purchase prices used by economic agents in their production processes" (DANE, 2019, p. 15).
} 


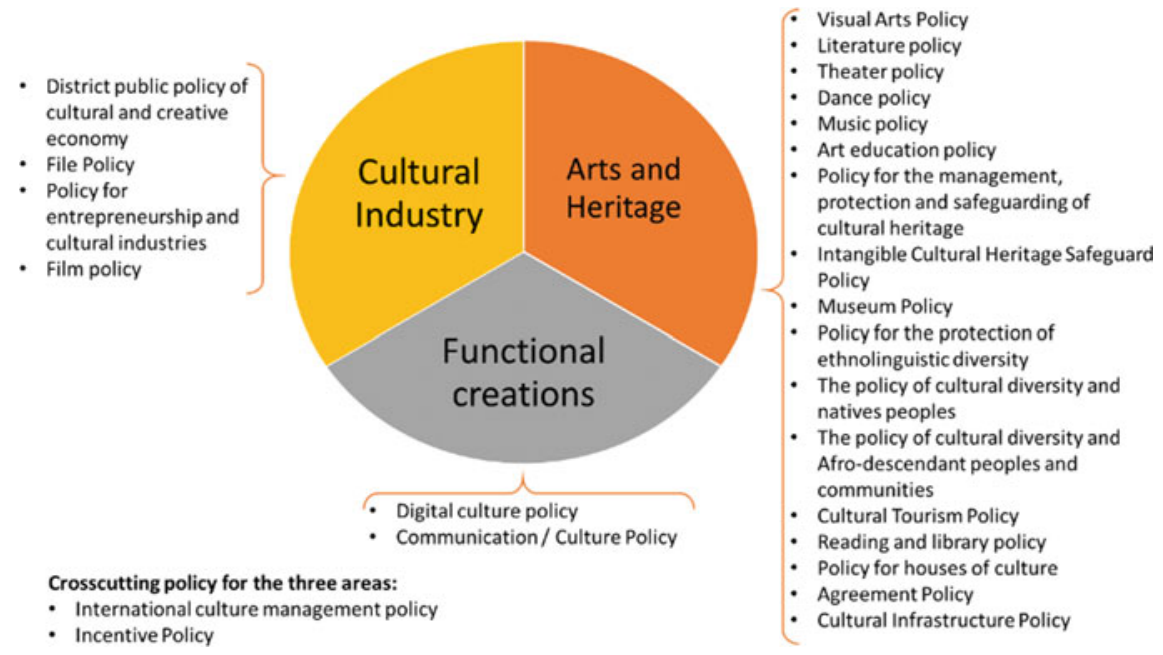

Fig. 1 Public policies by CCI area in Colombia (Source Authors' own based on data from the Colombian Ministry of Culture [2010])

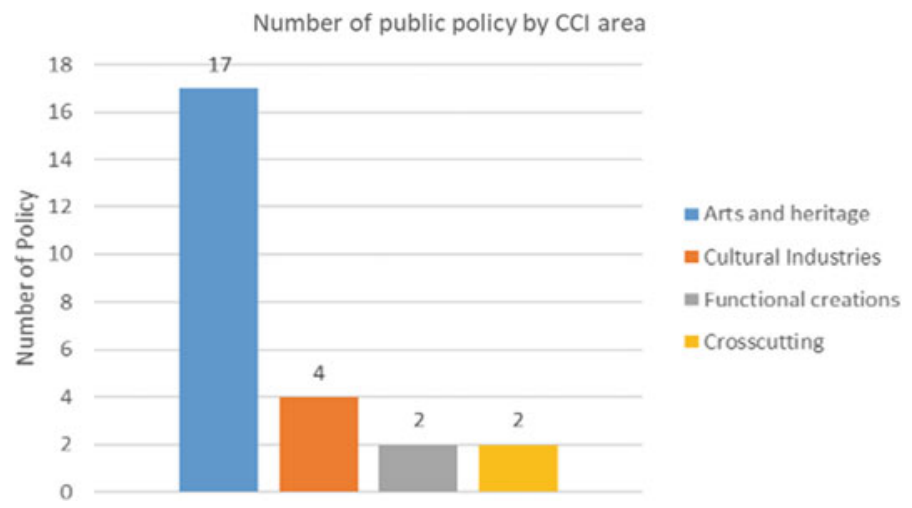

Fig. 2 Number of CCI policies by area (Source Authors' own based on data from the Colombian Ministry of Culture [2010])

Public Policy for the Cultural and Creative Economy included in the aforementioned cultural industry area of Colombian CCI policies.

Their general objective is to develop them through five strategic lines: (i) promotion of cultural industry products and services; (ii) improving access to financing mechanisms; (iii) supporting local initiatives for the development of cultural industries; (iv) expansion of specialised training; (v) and the promotion of new technologies in the development of business models for cultural industries (Conpes, 2019, p. 16). These lines are consistent with the areas of public intervention mentioned above proposed by the Organization of Ibero-American States (2016). 
One of this local strategy's main objectives is to propose the creation of infrastructures to encourage stakeholder interaction, generating scenarios for the exchange of knowledge to enhance their creative processes, which should result in CCI implementation (Organización de Estados Iberoamericanos, 2016). For this reason, the national government, aligned with the Bogota Council, promoted the creation of a local cluster known as an ODA (Orange Development Area) focused on offering CCIrelated academic programmes, given that in 2010, 32\% of these types of academic training options were estimated to be inactive (Ministerio de Cultura, Ministerio de Comercio, \& Planeación, 2010).

ODAs can be generated in two ways (Alcaldía de Bogotá, 2019): (i) induced as the result of public policies or government programmes, which aim to transform abandoned spaces and marginal areas into new drivers for social and cultural development (p. 25), (ii) and spontaneous as the result of economic activities linked to the cultural and creative economy that evolve spontaneously within the territory. These ODAs have a high density of cultural equipment and significant numbers of training courses related to the sector (p. 27).

\subsection{Policies Focused on Music in Colombia}

In Colombia, music has historically been the way for different cultures to promote their cultural heritage from primitive communities to the present day. Music is conceived as part of communities' social development process (Ministerio de Cultura de Colombia, 2010). In 1982, Law 23 was published with the specific aim of protecting copyright and defending intellectual, heritage and cultural rights (Congreso de Colombia, 1982). This Law was modified in 2018 by Law 1915, adding other provisions related to copyright (Congreso de Colombia, 2018).

The artists in each region permeate their music and lyrics with their own individual hallmark given by cultural diversity. The music in each municipality and region describes their own local traditions, as well as the variety of different instruments that each region has. It depends on the natural inputs that the land provides to create it, as well as on the influence of the migrants who have settled in each region, bringing part of their own culture. Music has developed in Colombia within this mix of materials, culture and traditions (Ministerio de Cultura de Colombia, 2010). Thus, given this musical wealth, the government created the National Music Plan for Coexistence (PNMC), which considered the cultural and professional dimensions of the music production cycle.

In any case, the first musical policies and programmes in Colombia were implemented by the Ministry of National Education through the so-called Colcultura, an organisation created in 1968 whose objective was: "the creation, strengthening and projection of national symphonic groups (bands, choirs and symphony orchestras) and the management of operas and concerts at the Colón Theatre" (Ministerio 
de Cultura de Colombia, 2010, p. 139). Additionally, the CREA ${ }^{2}$ programme was launched as "an expedition through Colombian culture" to locally disseminate the popular music of each of the country's regions.

From 1997 to 2002, with the creation of the Ministry of Culture, new music promotion policies were developed through the National Council for Economic and Social Policy (CONPES) (Ministerio de Cultura de Colombia, 2010, p. 139). However, it was not until 2006 that the budgets to ensure the sustainability of musical traditions increased substantially, with the "Guidelines for the strengthening of the National Music Plan for Coexistence".

This PNMC was established through the 2002-2006 National Development Plan and served as a guide for the mayors and governors of Colombia to promote education and musical practice at the municipal, regional and national levels. This plan linked training, research, infrastructure, entrepreneurship, financing and the coordination of public musical activities (Ministerio de Cultura de Colombia, 2010). The objective was to strengthen the musical heritage of each region and extend its outreach on the national and international markets. In this sense, the plan promoted national projects and initiatives at international level organised through multilateral organisations and cooperating countries (Ministerio de Cultura de Colombia, 2010, p. 51).

At national level, public entertainment was strengthened through Law 1493 passed in 2011, which sought to formalise the performing arts through instruments such as increased economic resources, tax incentives and the simplification of procedures for holding events (Ministerio de Cultura, 2011). Musical events are held in all regions of the country, with both the Pacific and Atlantic coast areas being rich in rhythms and musical creations. It is important to highlight that there are strongly rooted Afrodescendant and indigenous cultures on the coasts that still preserve their cultural and musical traditions, which date back to the time of the conquest.

The majority of musical production in the country, however, is in the large cities where industry is concentrated. Of a total of 599 companies dedicated to music, $37 \%$ are in Bogota, $16 \%$ are in the region of Antioquia and $13 \%$ in Valle del Cauca. It is important to note that the region of Antioquia is the only one in the country with its own Regional Music Plan (2014-2020), which has strengthened the music industry and the international outreach of musicians and singers.

Despite the formality of the rules and laws, piracy has been one of the hurdles for musical entrepreneurs. To combat this, in 2006, the Congress of the Republic approved Law 1032, which amended articles in the Colombian Penal Code to further tighten both prison and economic penalties for anyone engaging in illegal telecommunications activities, and violations of copyright and related rights (Congreso de la República, 2006).

Efforts to protect the music industry, especially in terms of copyright, are aimed at preserving the culture provided by music and at generating incentives that encourage more Colombian citizens to pursue a career in music. However, as shown in Fig. 3, only 599 of the 7,427 companies in the creative, artistic and entertainment sector belong to the music creation area, which represents only $8 \%$ of the total. Live musical

\footnotetext{
${ }^{2}$ The Crea Program is a strategy that is part of the District Development Plan 2020-2024.
} 


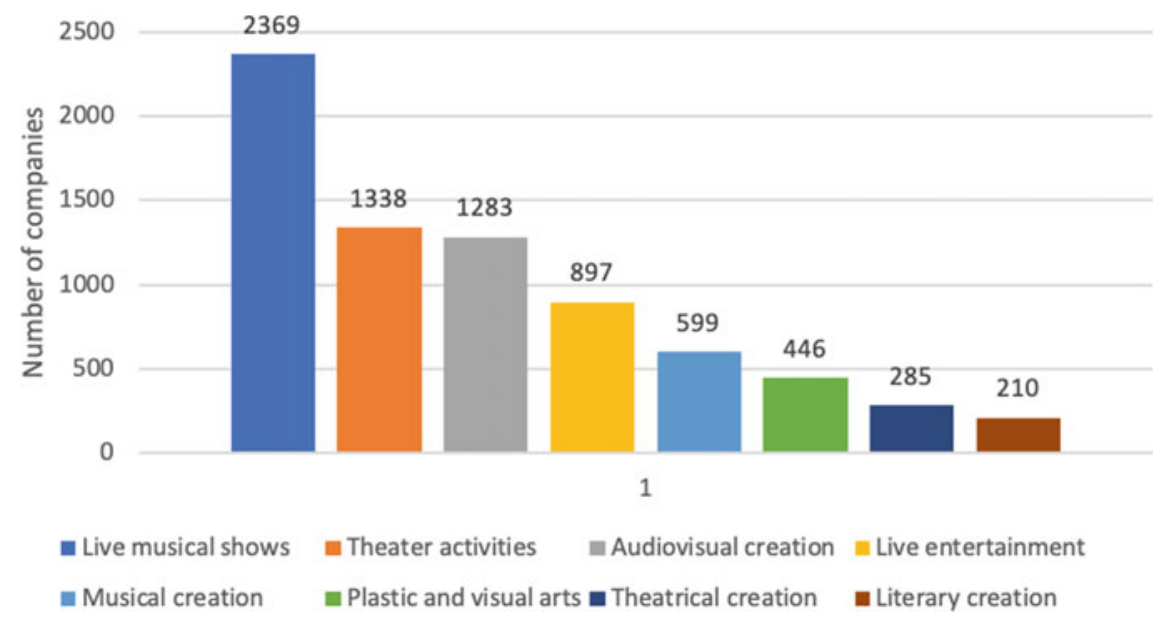

Fig. 3 Total companies that make up the creative, artistic and entertainment sector (Source Geoviewer Business Directory 2018 [DANE, 2018])

performance activities, meanwhile, represent $31 \%$ of all creative, artistic and entertainment activities, hence the importance of Law 1493 passed in 2011 on public performances in the country.

For Colombia, it is of vital importance to protect copyright given the high levels of informality that exist in the country. For this reason, since 1982, laws have been enacted and modified to protect Colombian authors and musicians. Likewise, as part of its instruments to motivate musical entrepreneurs, in 2004, Law 881 established guidelines to pay tribute to the great national artists who have created and conserved the country's musical heritage over the last 500 years (Congreso de Colombia, 2004).

\section{Characterisation of CCIs in Bogota: Identifying Clusters}

The methodology that we propose to analyse public policies aimed at enhancing the cultural and creative industries and their clusters, specifically in the music sector, is a descriptive study to identify their characteristics and elements and discover possible associations in terms of behaviour. It is an analytical research method, since our aim is to identify the features that characterise public CCI policies and CCI clusters, and ultimately establish relationships between them. The main sources of information used were secondary sources (texts, magazines, national and international documents) centring on establishing a relationship between CCI policy and cluster literature, as well as their implications in their environment.

We characterised CCI companies and clusters in Bogota by applying statistical and geographical techniques to the database of Bogota companies engaged in this sector (Méndez Álvarez, 2006). Thus, we identified 113,685 firms located in the 20 
Table 1 Total number of CCI in Bogota by activity

CCI in Bogota: total and partial inclusion activities

\begin{tabular}{|c|c|c|c|}
\hline Area & Sector & No. companies & $\%$ Sector \\
\hline \multirow[t]{6}{*}{ Arts and heritage } & $\begin{array}{l}\text { Associative activities and } \\
\text { regulation }\end{array}$ & 17,311 & 41 \\
\hline & $\begin{array}{l}\text { Manufacturing activities in the } \\
\text { creative economy }\end{array}$ & 13,226 & 31 \\
\hline & $\begin{array}{l}\text { Arts education, culture and } \\
\text { creative economy }\end{array}$ & 5,732 & 13 \\
\hline & $\begin{array}{l}\text { Heritage cultural material and } \\
\text { immaterial }\end{array}$ & 3,265 & 8 \\
\hline & Performing arts and shows & 2,243 & 5 \\
\hline & Visual arts & 811 & 2 \\
\hline \multicolumn{2}{|c|}{ Total number of arts and heritage companies } & 42,588 & 100 \\
\hline \multirow[t]{4}{*}{ Industries cultural conventional } & Editorial & 22,773 & 78 \\
\hline & Audiovisual & 4,959 & 17 \\
\hline & $\begin{array}{l}\text { News agencies and other } \\
\text { information services }\end{array}$ & 739 & 3 \\
\hline & Phonographic & 738 & 3 \\
\hline \multicolumn{2}{|c|}{ Total number of cultural industry companies } & 29,209 & 100 \\
\hline \multirow{3}{*}{$\begin{array}{l}\text { Creations functional, new media } \\
\text { and software }\end{array}$} & Design & 18,121 & 43 \\
\hline & $\begin{array}{l}\text { Digital media and content } \\
\text { software }\end{array}$ & 15,441 & 37 \\
\hline & Advertising & 8,326 & 20 \\
\hline \multicolumn{2}{|c|}{ Total number of functional creations companies } & 41,880 & 100 \\
\hline \multicolumn{2}{|l|}{ Total general companies in the CCI } & 113,685 & \\
\hline
\end{tabular}

Source Authors' own based on DANE (2018)

city districts. Table 1 shows the total number of CCIs in Bogota, which are divided into thirteen sectors belonging to three main areas. Of the 113,685 existing CCIs, 42,588 belong to the arts and heritage sector, 29,209 to the cultural industry and 41,888 to functional creations.

A second step was to identify clusters. In the first place, we considered induced and spontaneous ODAs (Alcaldía de Bogotá, 2019). Thus, in 8 of the 20 districts in Bogota, 11 creative clusters were identified: nine created by citizens from a downtop perspective and two created by the national government from a top-down viewpoint. Figure 4 shows that the Chapinero district concentrated the largest number of conglomerates ( 4 of the 11). On the other hand, the two clusters promoted by the government are located in areas of Bogota that need regeneration to increase their economic development: Martires/Bronx and Fontibon.

The two ODAs created by the government have regenerated two parts of the city with complex social problems, such as drug addiction, prostitution, insecurity and 


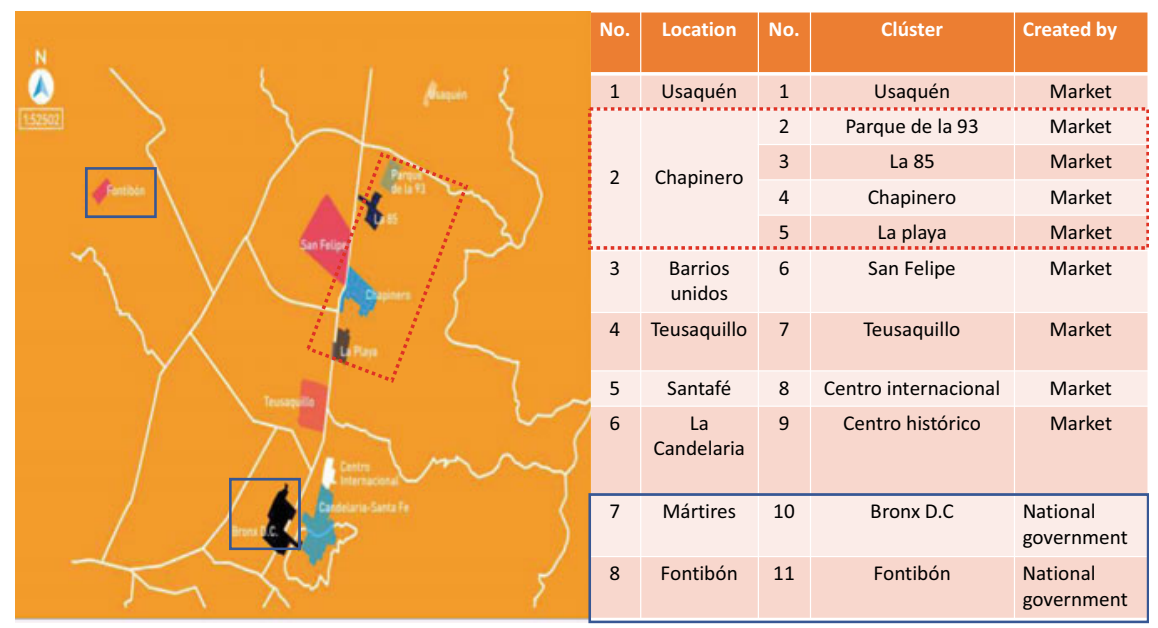

Fig. 4 CCI clusters (ODAs) in Bogota D.C. (Source Authors' own based on the Secretariat of Culture of Bogota Alcaldía de Bogotá [2019])

violence (Gutiérrez \& Sáez, 2018). In one of them, the government has created a techniques and technological education centre that offers artistic and cultural programmes, generating a process of urban revitalisation in these spaces (Harvey, 2015; Scott, 1997, 2010). Therefore, CCI policies and instruments focused on the development of collaborative spaces have helped to strengthen different CCI clusters in Bogota. In general, we can observe that public policies for CCIs have encouraged the development of clusters and the growth of CCIs in Bogota (Alcaldía Mayor de Bogotá, 2019).

\section{Regional Public Policies with Emphasis on Music Industries}

Public policies for the music industries are created by the Ministry of National Culture, but they are administered by individual regions in Colombia. Likewise, each region can issue its own public policies according to the characteristics of its own culture. In the particular case of Bogota, the implementation of public music policies is carried out through the District Institute of the Arts, whose objective is the promotion, strengthening and development of music from a human and artistic standpoint. Some of the public policy instruments focus on providing economic incentives, scholarships, awards, internships and artist residencies that promote the musical process in the city of Bogota, from the creation to the dissemination of musical projects (Ministerio de Cultura de Colombia, 2010). 
In 2012, the UNESCO included Bogota in its network of "creative cities of music", a distinction earned by this city in recognition of its more than 70 music festivals, which have made Bogota the most important musical centre in Colombia regarding the culture satellite account ${ }^{3}$ and the biennial culture survey (Secretaría de Cultura, 2012).

As shown in Table 2, public music policies have played a dominating role in adding economic value to the city of Bogota, where music has a total share of $4 \%$ in the area of conventional cultural industries and $18.3 \%$ in the area of arts and heritage. Thus, it contributes $€ 92,527,750$ to the total value added by the cultural and creative industries in the city of Bogota.

Table 2 demonstrates that music has an active role in two of the three cultural and creative industry areas. It has been strengthened as a result of public music policies and the instruments for their implementation.

\section{Conclusions}

The concept of cultural and creative industries has evolved since its inception, with music being one of the most representative sectors. Therefore, the importance of public policies centring on music for the promotion, strengthening and development of this sector in Colombia and, especially, in the capital city, Bogota, D.C., must be highlighted.

On the one hand, public policies can generate strategies to promote ODAs, for example, designing spaces, eliminating bureaucracy, improving managerial and entrepreneurial skills, and improving financial support. On the other hand, they are essential to promote the consumption of cultural and creative products and services (Rius-ulldemolins et al., 2016).

As shown in the clusters identified in some Bogota districts, CCI clusters promote knowledge which is transmitted and absorbed (Boix et al., 2015). Moreover, there are opportunities to create more ODAs in another 12 districts (Conpes, 2019). To do this, the Bogota local government published a guide offering recommendations to apply the model. Furthermore, a specific "Creative Economy" area has been created inside the Secretary of State of Culture to develop more public policies.

However, the political instability in Colombia may have an impact on the future of these policies given that CCIs are the flagship project of the current government. This means that its opponents associate CCIs with a political party and not an economic point of view.

Finally, the importance of music in Bogota D.C. has been recognised by the UNESCO for its contributions to adding economic value to the cultural and creative industries in Colombia. These advances have been achieved thanks to the creation, development and implementation of public policies that facilitate the musical growth

\footnotetext{
${ }^{3}$ The satellite account will help to assess the economic contribution of cultural industries and activities to GDP (UNESCO, 2009, p. 35).
} 
Table 2 Added value of the cultural and creative industry in Bogota D.C.

\begin{tabular}{|c|c|c|c|c|c|}
\hline Area & Value added 2018 & $\%$ & Sector & Value added 2018 & $\%$ \\
\hline \multirow{3}{*}{$\begin{array}{l}\text { Creations } \\
\text { functional, new } \\
\text { media and software }\end{array}$} & \multirow[t]{3}{*}{$€ 1,841,562,250$} & \multirow[t]{3}{*}{61.3} & $\begin{array}{l}\text { Digital media and } \\
\text { content software }\end{array}$ & $€ 1,094,849,500$ & 59.5 \\
\hline & & & Advertising & $€ 592,381,750$ & 32.2 \\
\hline & & & Design & $€ 154,331,000$ & 8.4 \\
\hline \multicolumn{4}{|c|}{ Total number of functional creations companies } & $€ 1,841,562,250$ & 100 \\
\hline \multirow{4}{*}{$\begin{array}{l}\text { Industries cultural } \\
\text { conventional }\end{array}$} & \multirow[t]{4}{*}{$€ 821,324,500$} & \multirow[t]{4}{*}{27.8} & Audiovisual & $€ 514,125,750$ & 62.6 \\
\hline & & & Editorial & $€ 215,693,250$ & 26.3 \\
\hline & & & $\begin{array}{l}\text { News agencies } \\
\text { and other } \\
\text { information } \\
\text { services }\end{array}$ & $€ 55,725,000$ & 6.8 \\
\hline & & & Phonographic & $€ 35,780,500$ & 4.4 \\
\hline \multicolumn{4}{|c|}{ Total number of cultural industry companies } & $€ 821,324,500$ & 100 \\
\hline \multirow[t]{6}{*}{ Arts and heritage } & \multirow[t]{6}{*}{$€ 309,990,250$} & \multirow[t]{6}{*}{10.9} & $\begin{array}{l}\text { Arts education, } \\
\text { culture and } \\
\text { creative economy }\end{array}$ & $€ 155,291,250$ & 50.1 \\
\hline & & & $\begin{array}{l}\text { Associative } \\
\text { activities and } \\
\text { regulation }\end{array}$ & $€ 66,619,750$ & 21.5 \\
\hline & & & $\begin{array}{l}\text { Performing arts } \\
\text { and shows }\end{array}$ & $€ 30,803,500$ & 9.9 \\
\hline & & & $\begin{array}{l}\text { Manufacturing } \\
\text { activities in the } \\
\text { creative economy }\end{array}$ & $€ 29,342,500$ & 9.5 \\
\hline & & & $\begin{array}{l}\text { Heritage cultural } \\
\text { material and } \\
\text { immaterial }\end{array}$ & $€ 25,943,750$ & 8.4 \\
\hline & & & Visual arts & $€ 1,989,250$ & 0.6 \\
\hline \multicolumn{4}{|c|}{ Total added value of arts and heritage } & $€ 309,990,000$ & 100 \\
\hline \multicolumn{4}{|c|}{ Total added value CCI in Bogota D.C. } & $€ 2,972,876,750$ & 100 \\
\hline
\end{tabular}

Source Authors' own based on DANE (2018)

of the capital city of the country, making Bogota a hub for the world's largest musical shows and concerts.

Due to the above and given the potentialities of music at cultural, social and economic level for the city and therefore for the country, there is a primary need to continue creating and strengthening public policies and instruments for the development of Bogota and the Colombian music industry. 


\section{References}

Alcaldía de Bogotá. (2019). Guía Práctica para la Creación de Áreas de Desarrollo Naranja. In Política Pública Distrital de Economía Cultural y Creativa (Secretaria). Bogotá. https://www.culturarecreacionydeporte.gov.co/sites/default/files/guia_practica_p ara_la_creacion_de_areas_de_desarrollo_naranja.pdf.

Baculáková, K. (2018). Cluster analysis of creative industries in the regions and districts of Slovakia. Theoretical and Empirical Researches in Urban Management; Bucharest, 13(3), 74-89. https:// search.proquest.com/docview/2095705499?accountid=28445.

Bardach, E. (1998). Los ocho pasos para el análisis de políticas públicas. Grupo Editorial Miguel Ángel Porrua.

Bialic-Davendra, M., Bednář, P., Danko, L., \& Matošková, J. (2016). Creative clusters in Visegrad countries: Factors conditioning cluster establishment and development. Bulletin of Geography: So-Cio-Economic Series, 32(32), 33-47. https://doi.org/10.1515/bog-2016-0013.

Binns, L. (2005). Capitalising on culture: An evaluation of culture-led urban regeneration policy. https://arrow.tudublin.ie/futuresacart.

Boix, R., Hervás-Oliver, J. L., \& De Miguel-Molina, B. (2015). Micro-geographies of creative industries clusters in Europe: From hot spots to assemblages [Article]. Papers in Regional Science, 94(4), 753-772. https://doi.org/10.1111/pirs.12094.

Boix, R., Lazzeretti, L., Hervàs, J. L., \& De Miguel, B. (2011). Creative clusters in Europe: A microdata approach. Valencia, Editorial ERSA. New Challenges for European Regions and Urban Areas in a Globalised World, 1-33.

Colombian Ministry of Culture. (2010). Cultural Policy Compendium. In Colombian Ministry of Culture. http://www.mincultura.gov.co/areas/fomento-regional/Documents/Compen dio-Políticas-Culturales.pdf\%5Cn. http://www.mincultura.gov.co/ministerio/politicasculturales/ compendio-politicas-culturales/Paginas/default.aspx.

Congreso de Colombia. (1982). Ley 23. Diario Oficial (1982). http://derechodeautor.gov.co:8080/ documents/10181/182597/23.pdf/a97b8750-8451-4529-ab87-bb82160dd226.

Congreso de Colombia. (2004). Ley 881 De 2004. https://www.funcionpublica.gov.co/eva/gestor normativo/norma_pdf.php?i=12916.

Congreso de la República. (2006). Ley 1032 De 2006. 2006 Diario Oficial § (2006). http://www.sec retariasenado.gov.co/senado/basedoc/ley_1032_2006.html\#: :text=Incurrir\%C3\%A1\%20en\% 20prisi\%C3\%B3n\%20de\%20cuatro\%20(4)\%20a\%20ocho\%20(8,1.

Congreso de Colombia. (2018). Ley 1915. Diario Oficial (2018). http://es.presidencia.gov.co/nor mativa/normativa/LEY\%201915\%20DEL\%2012\%20DE\%20JULIO\%20DE\%202018.pdf.

Conpes, D. C. (2019). Política Pública Distrital De Economía Cultural Y Creativa 2019-2038. Editorial Departamento Nacional de Planeación.

Cooke, P., \& Lazzeretti, L. (2008). Creative cities, cultural clusters and local economic development (P. Cooke \& L. Lazzeretti, Eds.). Edward Elgar.

Cooke, P., Martin, R., \& Asheim, B. T. (2006). Clusters and regional development: Critical reflections and explorations (P. Cooke, R. Martin, \& B. T. Asheim, Eds.). Routledge.

DANE. (2018). Departamento Nacional de Estadística. Geoportal, Directorio de empresas. https:// geoportal.dane.gov.co/geovisores/economia/directorio-estadistico-de-empresas/?1t=4.456007 $353293281 \& \lg =-73.2781601239999 \& \mathrm{z}=5$.

DANE. (2019). Economía Naranja Segundo reporte 2019. https://www.dane.gov.co/files/invest igaciones/pib/sateli_cultura/economia-naranja/presentacion-rp-2do-reporte-economia-naranja2014-2018.pdf.

Gutiérrez, C. A. B., \& Sáez, F. A. A. (2018). La producción de marginalidad urbana: El proceso socio-histórico, emergencia y configuración del Bronx en Bogot [The production of urban marginality: The sociohistorical process, emergency and configuration of the Bronx in Bogot]. IMAGONAUTAS, 107-128. 
Harvey, D. (2015). Od menedżeryzmu do przedsiębiorczości: transformacja procesu rządzenia miastami w późnym kapitalizmie z wprowadzeniem Boba Jessopa. Zarzadzanie Publiczne, 3(3(33)/2015), 84-106. https://doi.org/10.15678/zp.2015.33.3.06.

Islam, F. (2000). Socioeconomy of innovation and entrepreneurship in a cluster of SMEs in emerging economies. Emerald Insight. https://doi.org/10.1108/10595421011047451.

Méndez Álvarez, C. E. (2006). Metodología, diseño y desarrollo del proceso de investigación con énfasis en ciencias empresariales (Limusa Nor).

Ministerio de Cultura. (2011). Ley 1493 de espectaculos públicos. https://www.mincultura.gov.co/ areas/artes/ley-de-espectáculos-publicos/Documents/Ley_1493_2011.pdf.

Ministerio de Cultura de Colombia. (2010). Compendio de políticas culturales. https://www.min cultura.gov.co/ministerio/politicas-culturales/compendio-politicas-culturales/Documents/com pendiopoliticas_artefinalbaja.pdf.

Ministerio de Cultura, Ministerio de Comercio, I. y T., \& Planeación. (2010). D. N. de. Política nacional para la promoción de las industrias culturales en Colombia (Documento Conpes 3659). Departamento Nacional de Planeación. https://culturayeconomia.org/blog/documento-conpes3659-politica-nacional-para-la-promocion-de-las-industrias-culturales-en-colombia/.

Organización de Estados Iberoamericanos. (2016). Estudio comparativo de cultura y desarrollo en Iberoamérica. https://oibc.oei.es/otros_documentos/Estudio_CD_OEI.pdf.

Rius-ulldemolins, J., Arturo, J., \& Arostegui, R. (2016, March). Treinta años de políticas culturales en España.

Ruiz, J. E., \& Marulanda, V. (1976). La Política cultural en Colombia. https://unesdoc.unesco.org/ ark:/48223/pf0000134155?posInSet=1\&queryId=90be9687-99ec-4bb5-9c96-d1efb87084ac.

Scott, A. (2010). Cultural economy and the creative field of the city. Geografiska Annaler Series B-Human Geography, 92B(2), 115-130. http://apps.webofknowledge.com.ezoris.lib.hokudai.ac. jp/full_record.do?locale=en_US\&errorKey=\&page=1\&qid=16\&log_event=yes\&viewType=ful IRecord\&SID=U11 efa4WINjqZNnH3Jy\&product=WOS\&doc=9\&search_mode=DaisyOneC lickSearch.

Scott, A. J. (1997). The cultural economy of cities. International Journal of Urban and Regional Research, 21(2), 323-339. https://doi.org/10.1111/1468-2427.00075.

Secretaría de Cultura, R. y D. (2012). Bogotá es Música I Secretaría de Cultura, Recreación y Deporte. Retrieved November 19, 2020, from https://www.culturarecreacionydeporte.gov.co/es/ areas-de-trabajo/practicas-artisticas/musica.

UNCTAD. (2008). Creative economy report 2008. https://unctad.org/en/Docs/ditc20082cer_en.pdf.

UNESCO. (2009). 2009 UNESCO Framework for Cultural Statistics. In UNESCO Institute for Statistics (Vol. 5). http://www.uis.unesco.org.

UNCTAD. (2010). Creative economy report 2010. Switzerland.

UNESCO. (2013). Creative economy report. http://academy.ssc.undp.org/creative-economy-rep ort-2013.

UNESCO. (2019). Culture 2030 indicators. UNESCO.

UNESCO Forum of Ministers of Culture 2019. (2019). UNESCO website: https://en.unesco.org/ themes/protecting-our-heritage-and-fostering-creativity/forum-of-ministers-of-culture-2019.

Zheng, J., \& Chan, R. (2014). The impact of "creative industry clusters" on cultural and creative industry development in Shanghai. City, Culture and Society, 5(1), 9-22. https://doi.org/10.1016/ j.ccs.2013.08.001. 
Open Access This chapter is licensed under the terms of the Creative Commons Attribution 4.0 International License (http://creativecommons.org/licenses/by/4.0/), which permits use, sharing, adaptation, distribution and reproduction in any medium or format, as long as you give appropriate credit to the original author(s) and the source, provide a link to the Creative Commons license and indicate if changes were made.

The images or other third party material in this chapter are included in the chapter's Creative Commons license, unless indicated otherwise in a credit line to the material. If material is not included in the chapter's Creative Commons license and your intended use is not permitted by statutory regulation or exceeds the permitted use, you will need to obtain permission directly from the copyright holder.

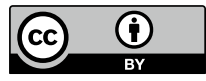

